\title{
New UHPLC-MS/MS Characterization of Ethanolic Extract from Talipariti elatum Sw. (Malvaceae)
}

\author{
Loïk Sylvius ${ }^{1}$, Juliette Smith-Ravin ${ }^{1}$, Odile Marcelin ${ }^{1}$, Stéphanie \\ Morin' ${ }^{1}$, Max Monan², Frantz François-Haugrin² and José González ${ }^{3 *}$ \\ ${ }^{1}$ Groupe de Recherche BIOSPHERES, Campus de Schoelcher, Martinique, French \\ West Indies \\ ${ }^{2}$ Association Pour la Recherche Sur la Valorisation des Ressources Naturelles de la \\ Martinique (ARVARNAM), Quartier Thoraille, Martinique, French West Indies \\ ${ }^{3}$ Facultad de Educación en Ciencias Técnicas, UCP "Enrique José Varona", La \\ Habana, Cuba \\ *Corresponding Author: José González, Facultad de Educación en Ciencias \\ Técnicas, UCP "Enrique José Varona", La Habana, Cuba.
}

Received: March 08, 2021

Published: May 11, 2021

(C) All rights are reserved by José González., et al.

\begin{abstract}
From the red petals of the flowers from Talipariti elatum that grows in Martinica a direct UHPLC analysis was done to get the chemical composition from ethanolic extracts of this plant's component. Thirty compounds have thus been identified, 26 of which were reported for the first time in the flowers of this spice by RP-HPLC coupled to a DAD detector and to a tandem ion trap mass spectrometer in order to obtain a UV profile and a spectrum of fragmentations in negative mode making it possible to achieve provisional identification. Among them, various gossypetin- $O$-derivatives were tentatively identified in the sample with another three chemical components previously reported by our research team.
\end{abstract}

Keywords: UHPLC-DAD-ESI-MS/MS; Talipariti; flavonoids; Petals; Chemical-compounds

\section{Introduction}

Talipariti elatum S.w is a tree native of Cuba and Jamaica. It is called "Majagua azul" in Cuba, "Mahot bleu" or "Mahot de montagne" in Martinique. It produces beautiful flowers throughout the year, which changes colour from bright yellow to crimson (Figure 1). Only two of 22 spices are present in Cuba, Talipariti elatum var. macrocarpum and Talipariti tiliaceum var. tiliaceum, and from this last one, a sub specie var. pernambucense [1].

Two phytodrugs "Ifmefasma" and "Flormaj" have already been manufactured and marketed in that country [2]. Numerous studies relating to its biological activities have been carried out and many of these properties have been attributed to the presence of gossypitrin (gossypetin-7-O-glucoside) [3-6]. It was then demonstrated by the ARVARNAM research group that the main product isolated by precipitation of the hydroalcoholic extract is not gossypitrin but gossypetin-3'-O-glucoside [7].
There is very little information on its phytochemical constituents in the literature, and the petals have shown the presence of many flavonoids. Twelve compounds could be identified and 8 highlighted for the first time in 2017. However, many others remain to be identified. There is therefore a need to improve the technique and to expand bibliographic research.

\section{Aim of the Study}

The aim of the present study was to determine the chemical composition in ethanolic extract at $95 \%$ from the petals of the flowers of Talipariti elatum (S.w) in Martinica using and UHPLC-MS/ MS system.

\section{Materials and Methods \\ Plant material}

Flowers were collected in January 2016 along the track road in Balata forest located in Martinica. A voucher specimen is deposit- 


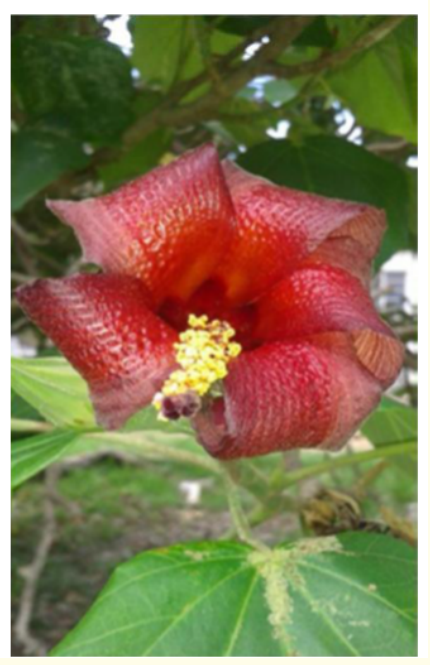

Figure 1: Red flower of T. elatum.

ed and registered in French Pharmacopeia as Fournet 1752 (4232 Guad). Martinican specimen are registered as Hibiscus elatus Sw.

\section{Extract and samples preparation}

Extraction was carried out in a Soxhlet apparatus using the petals of flowers with ethanol at $95 \%$ as solvent. The extract was concentrated in a rotary evaporator (RE Start 300) until a volume of about $50 \mathrm{~mL}$.

HPLC-DAD-ESI-MS/MS procedures, instrumentation and parameters

UPLC has been used for the profiling and characterization of the metabolites contained in the extracts. The system used is a Dionex U3000 equipped with a DAD detector having a $\mathrm{C}_{18}$ analytical column (100 x 4.6mm particles, i.d: $3 \mu \mathrm{m})$. Solvent systems: $\mathrm{H}_{2} \mathrm{O}-0.1 \%$ Formic Acid $\left(\mathrm{H}_{2} \mathrm{O}\right)$ and Acetonitrile- $0.1 \%$ Formic Acid (Table 1).

\begin{tabular}{|l|c|c|}
\hline \multicolumn{1}{|c|}{ Time } & Solvents & Gradient \\
\hline 0 & $\mathrm{H}_{2} \mathrm{O}: \mathrm{CH}_{3} \mathrm{CN}$ & $80: 20$ \\
\hline 5 & $\mathrm{H}_{2} \mathrm{O}: \mathrm{CH}_{3} \mathrm{CN}$ & $80: 20$ \\
\hline 10 & $\mathrm{H}_{2} \mathrm{O}: \mathrm{CH}_{3} \mathrm{CN}$ & $0: 100$ \\
\hline 25 & $\mathrm{H}_{2} \mathrm{O}: \mathrm{CH}_{3} \mathrm{CN}$ & $0: 100$ \\
\hline 30 & $\mathrm{H}_{2} \mathrm{O}: \mathrm{CH}_{3} \mathrm{CN}$ & $80: 20$ \\
\hline 34 & $\mathrm{H}_{2} \mathrm{O}: \mathrm{CH}_{3} \mathrm{CN}$ & $80: 20$ \\
\hline
\end{tabular}

Table 1: UPLC gradient used in the research.
The HPLC is coupled to a Varian 500MS Mass Spectrometer equipped with an electrospray ionization chamber (ESI) used in negative mode at $5 \mathrm{KV}$ at a capillary temperature of $250^{\circ} \mathrm{C}$. The UV detector and the Mass Spectrometer are used in parallel. A split allows the post column eluent flow to be separated into 2 parts when the flow rate used is greater than $500 \mathrm{~L} / \mathrm{min}$. From a flow rate of $1 \mathrm{~mL} / \mathrm{min}, 400 \mu \mathrm{L} / \mathrm{min}$ are sent to the mass spectrometer and around $600 \mu \mathrm{L} / \mathrm{min}$ to the trash.

Data was acquired in positive or negative mode using the TDDS option "Turbo Data Dependent Scanning" to automatically obtain ion fragmentation spectra that allow the identification of compounds. These mass spectrometry data were compared with free access databases such as "Massbank", "Spider mass DB", the "in-house" database or data from the literature. If this procedure did not allow identification, an attempt to elucidate the structure was carried out manually. Fragmentation spectra $\left(\mathrm{MS}^{2}\right)$ in negative mode were carried out for the structural elucidation of each of the compounds.

\section{Results and Discussion}

Analysis of the hydroalcoholic extract by UPLC-DAD-MS/MS

UPLC-DAD-MS/MS is a method of choice for the identification of secondary metabolites and other constituents of plant extracts. This approach, which is being standardized in our laboratory, applies the same analytical scheme. Extraction, separation by liquid chromatography, UV detection (DAD) and fragmentation of molecular ions by mass spectrometry. It allows the comparison of mass spectra obtained with those obtained using standard products or mass spectra previously obtained and available in the literature.

Thus, each analysis contributes to a growing internal library of data. It is noted that without standards, this method provides a temporary identification of the compounds. That is to say, an identification of the skeletons of flavonoids, phenolic acids, saccharides and acyls, but not the positions of the links between these elements. Only identification by NMR will ultimately allow us to know the position between the different constituent elements of the molecule and thus determine the complete structure of the compound.

Fifty-four peaks were detected here as is shown in figure 2. Thirty temporary identifications, 26 of which were described for the first time in the ethanolic extract of Talipariti elatum (Sw.). We mainly found organic acids and flavonoids there.

\section{Organic acids}

Peaks 15 and 17 (probably an isomeric form) have been identified as hydroxyferulic acid hexoside in agreement with the pro- 


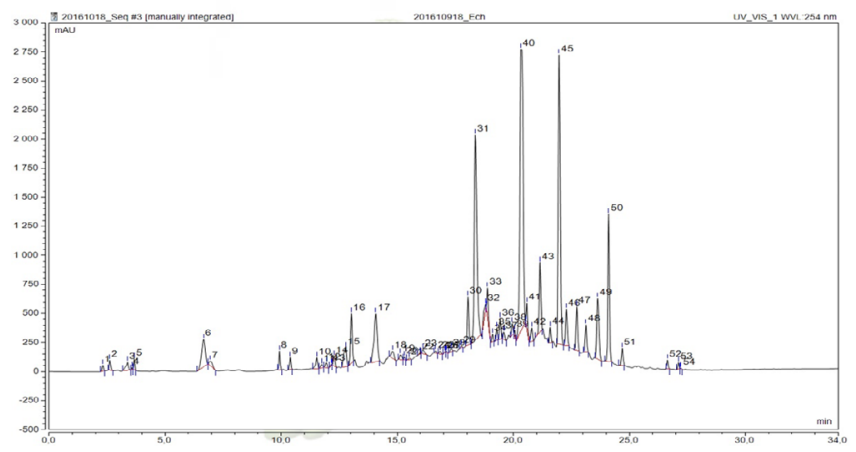

Figure 2: UV chromatogram of a hydroalcoholic extract of Talipariti elatum (Sw.) flower recorded at $254 \mathrm{~nm}$. 54 peaks were detected.

posed fragmentation for hydroxycinnamates [8]. The pseudomolecular ion (m/z 371) gives an ion at m/z 209 [M-H-hexosyl] which corresponds to the hydroxyferulic acid which generates an ion at $\mathrm{m} / \mathrm{z} 191$ [hydroxyferulate- $\mathrm{H}_{2} \mathrm{O}$ ]. It also produces an ion at $\mathrm{m} / \mathrm{z} 353$ $\left[\mathrm{M}-\mathrm{H}-\mathrm{H}_{2} \mathrm{O}\right]$.

Peak 16 is identified as a dihydrobenzoic acid glucoside. The most probable hypothesis is that is the protocatechuic acid because it is the only dihydrobenzoic acid that has already been described in the genus Hibiscus in the glycosylated or non-glycosylated form [9]. Oxo-dihydroxy-octadecenoic acid and ethyl cafeate were identified for peak 54 and peak 55 (almost undetectable), respectively. Those compounds are represented in figure 3.

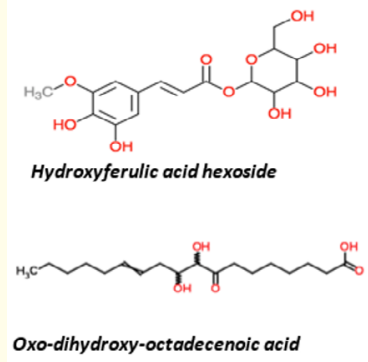

Oxo-dihydroxy-octadecenoic acid

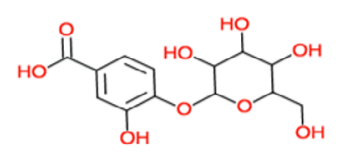

Dihydrobenzoic acid glucoside

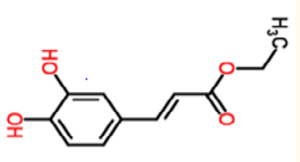

Ethyl cafeate
Figure 3: Organic acids identified in ethanolic extracts of the petals.

\section{Flavonoids}

The main fragment ions that have been found are fragments of flavonoids. The fragment ions found in the fragment spectra correspond to the fragment ions characteristic of flavonoid aglycons with the loss of neutral $\mathrm{H}, \mathrm{CO}, \mathrm{CO}_{2}, \mathrm{H}_{2} \mathrm{O}$ and the loss of glucose residue (s).

Peaks 22-38-40-42-43-45-50-47-51-52 are identified as quercetin and its glycosylated derivatives. We found the characteristic fragments of its pseudomolecular ion and its aglycon at m/z 301 $[\mathrm{MH}]^{-}$and its fragment ions $\mathrm{m} / \mathrm{z} 179\left({ }^{1,2} \mathrm{~A}^{-}\right)$and $151\left({ }^{1,2} \mathrm{~A}-\mathrm{CO}\right)$ (Figure 4) [10-12]. We also identify isorhamnetin (methylated quercetin) and its derivatives for peaks 18-31-36-39 as well as anthocyanins for peaks 13-20-23-25-26.

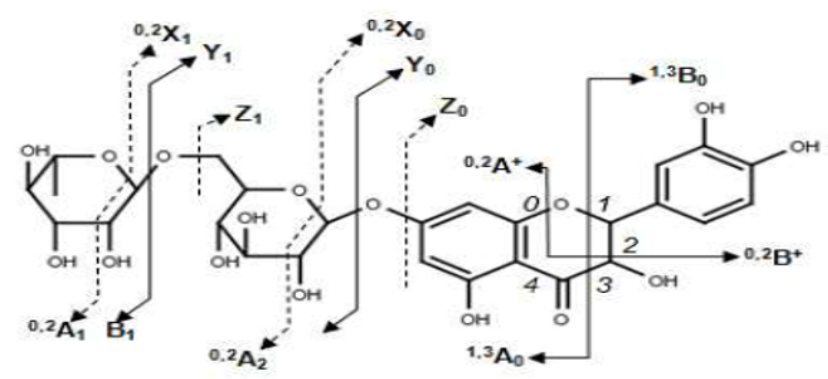

Figure 4: Nomenclature used for fragment ions of glucoside flavonoids.

(It is the fragmentation of quercetin-7-0-rutinoside that is described here. The glycoside ions were named in accordance with Domon and Costello, 1988; and aglycon ions in agreement with Ma., et al. 1997). (According to Pinheiro and Justino, 2012).

Only the catechin was found in the extract, so we can hypothesize that catechin is the building block of the basic structure of the proantocyanidin dimmer and trimmer that we found in this extract [13]. Regarding peaks 27-29-30-32-41-44-46-47-49-50 we identify gossypetin and its derivatives. They all have the pseudomolecular ion 317 [M-H] corresponding to the aglycon m/z 317 of gossypetin and the fragment ions specific to the fragmentation of this aglycon at m/z 299; m/z 271; m/z 195.2 [14]. The difference lies in the ramifications attached to this gossypetin aglycon (Figure 5).

Table 2 summarize the peak numbers, names, retention times, and fragmentation of those gossypetin derivatives found out in to 


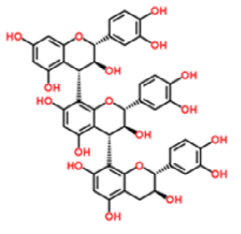

Proantocyanidin trimer

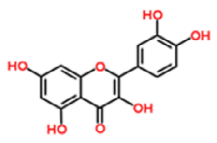

Quercetin

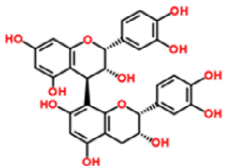

Proantocyanidine dimer

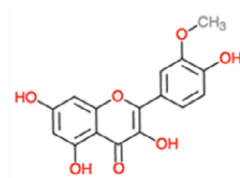

Isorhamnetin

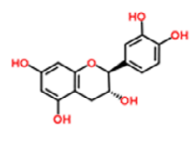

Catechin

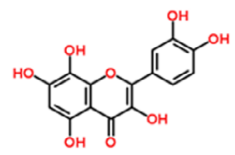

Gossypetin
Figure 5: Proposal structures of proantocyanidin, catechin and flavonoid aglycons. the total ethanolic extract from the petals of the flowers from $T$. elatum Sw.

Previously reported

Nine gossypetin derivatives were tentatively identified in ethanolic extracts of the petals of the flowers from T. elatum in this research, suggesting that this plant produce a lot of amount of phytochemical compounds that belongs to flavonoid group that perhaps have some great biological activities such as antioxidant, ant-asthmatic, antiviral, antimicrobial and anti-COVID 19 [15].

From those gossypetin derivatives, only three of them, were reported for a second time from this extracts, and the rest (6) were identified into the extracts for the first time. In this research none evidence of gossypetin aglycon was found out. The rest of peaks remain unknown.

\begin{tabular}{|c|c|c|c|c|c|c|}
\hline Peaks & Identification & $\begin{array}{l}\text { Retention time } \\
\text { (RT) }\end{array}$ & $\operatorname{MS}^{1}(\mathrm{~m} / \mathrm{z})$ & $\begin{array}{c}\text { MS }^{2} \\
\text { (m/z) (relative } \\
\text { intensitivy) }\end{array}$ & $\begin{array}{c}\text { MS }^{3} \\
\text { (m/z) (relative } \\
\text { intensitivy) }\end{array}$ & UV max \\
\hline 27 & $\begin{array}{l}\text { Gossypetin- } O \text { - } \\
\text { di-Glucoside- } O \text { - } \\
\text { Glucuronide }\end{array}$ & 17.281 & $817.7[\mathrm{M}-\mathrm{H}]^{-}$ & $\begin{array}{c}655.6[\mathrm{M}-\mathrm{Glu}]-(100 \%) \\
-641.6(98 \%)-637.7 \\
(33 \%)-479.6(1 \%)- \\
317.5(3 \%)\end{array}$ & $\begin{array}{c}479.7 \text { [M-Glu-Glucu- } \\
\text { ronide] (100) - } 317.5 \\
\text { [Gossypetin-aglycon] } \\
(30)\end{array}$ & - \\
\hline 29 & $\begin{array}{l}\text { Gossypetin-O- } \\
\text { glucoside-cou- } \\
\text { maroyl } \\
(-146)\end{array}$ & 17.796 & $801.5[\mathrm{M}-\mathrm{H}]^{-}$ & $\begin{array}{c}625.7 \text { [M-Glu] (100) } \\
\text { - } 317.5 \text { [M-Glu-Couma- } \\
\text { royl-Glu] (31) }\end{array}$ & $\begin{array}{c}485.7(11)-317.4 \\
(100)-299.5(5)- \\
271.5(2)\end{array}$ & $276-330$ \\
\hline $30-41^{*}$ & $\begin{array}{l}\text { Gossypetin- } O \text { - } \\
\text { Glucoside- } O \text { - } \\
\text { Glucuronide }\end{array}$ & $18.139 / 20.677$ & $655.1[\mathrm{M}-\mathrm{H}]^{-}$ & $\begin{array}{c}479.2 \text { [M-Glucor] (100) - } \\
317.2 \text { [M-Glucor-Hex] (2) } \\
\text { - } 270.6(1)\end{array}$ & $\begin{array}{c}317.4(100)-299.1 \\
(2)-287.4(1)-271.4 \\
(1)-195.3(1)\end{array}$ & 257-338 \\
\hline 32 & $\begin{array}{c}\text { Gossypetin- } O \text { - } \\
\text { Acetylhexose- } \\
O \text {-Glucoronide- } \\
\text { Carboxylated }\end{array}$ & 18.733 & $741.5[\mathrm{M}-\mathrm{H}]^{-}$ & $\begin{array}{c}697.6[\mathrm{M}-44](100) \\
-655.7[\mathrm{M}-44-42](4)- \\
521.6 .4(9)\end{array}$ & $\begin{array}{c}521.6(100)-479.4 \\
(1)-493.1(1)-317.1 \\
(1)\end{array}$ & 323 \\
\hline 44 & $\begin{array}{l}\text { Gossypetin- } O \text { - } \\
\text { acetylhexose- } O \text { - } \\
\text { Glucuronide }\end{array}$ & 21.643 & $697.6[\mathrm{M}-\mathrm{H}]^{-}$ & $\begin{array}{c}521.6(100)-479.4(2)- \\
493.1(3)-317.1(14)\end{array}$ & $\begin{array}{c}479.4(13)-461.6(8) \\
-317.1(100)-299.4 \\
(3)-271.4(1)-255.2 \\
(1)-195.3(1)\end{array}$ & $252-363$ \\
\hline $46^{*}$ & $\begin{array}{l}\text { Gossypetin-3'-O- } \\
\text { Glucoside }\end{array}$ & 22.287 & $479.0[\mathrm{M}-\mathrm{H}]^{-}$ & $\begin{array}{c}317.1[\mathrm{M}-\mathrm{Hex}](100)- \\
299.1[\mathrm{M}-18](1)\end{array}$ & $\begin{array}{c}299.3(100)-271.3 \\
(17)-255.2(11)- \\
195.2(22)-167.3 \\
(11)-139.2(10)\end{array}$ & $\begin{array}{l}251-276- \\
335-385\end{array}$ \\
\hline 47 & $\begin{array}{l}\text { Gossypetin- } O \text { - } \\
\text { acetylhexose- } O \text { - } \\
\text { acetylhexose }\end{array}$ & 22.554 & $725.6[\mathrm{M}-\mathrm{H}]^{-}$ & $\begin{array}{c}521.5 \text { [M-AcetylHex] } \\
(100)-[\text { M-2AcetylHex] } \\
317.5(31)\end{array}$ & $\begin{array}{c}479.7(5)-461.4(9)- \\
317.4(100)\end{array}$ & - \\
\hline 49 & $\begin{array}{l}\text { Gossypetin- } O \text { - } \\
\text { Acetylhexose }\end{array}$ & 23.212 & $521.4[\mathrm{M}-\mathrm{H}]-$ & $\begin{array}{c}479.3(9)-461.4(10)- \\
317.1(100)\end{array}$ & & $\begin{array}{r}256-277- \\
336-384 \\
\end{array}$ \\
\hline $50^{*}$ & $\begin{array}{l}\text { Gossypetin- } O \text { - } \\
\text { Glucoronide }\end{array}$ & 23.679 & $493.1[\mathrm{M}-\mathrm{H}]^{-}$ & $\begin{array}{l}317.2 \text { [M-Glucor] (100) - } \\
299.2 \text { [M-Glucor-18] (1) }\end{array}$ & $\begin{array}{c}299.1(100)-287.4 \\
(1)-271.4(14)- \\
195.3(23)-167.3 \\
(14)-139.3(11) \\
\end{array}$ & $258-374$ \\
\hline
\end{tabular}

Table 2: Gossypetin derivatives identified in ethanolic extracts of the petals. 


\section{Conclusion}

A simple and versatile analytical method, the "UPLC-DAD-ESIMS/MS" was implemented to allow direct identification of the constituents of the hydroalcoholic extract of the flower petals of Talipariti elatum (Sw.) that grow in Martinica. Thirty compounds have thus been identified, 26 of which were reported for the first time in this plant, principally, organic acids and flavonoids. Nine gossypetin derivatives were tentatively identified from that extract, and among them, six were characterized for the first time. Due to high sensitivity of this method, some constituents in minor amount were also identified. Furthermore, the results demonstrate that this method could provide full qualitative information of genus Talipariti. Further use of innovation studies like MALDI-TOFD-MS and HPLC-DAD-ESI-MS/MS-NMR are necessary for detection and characterization of minor unidentified compounds.

\section{Conflict of Interest}

The authors have declared no conflict of interest.

\section{Bibliography}

1. Areces Berazaín F and Fryxell A Paul. "Flora De La República de Cuba”. Fascículo 13 (2007): 43-47.

2. Roig JT. "Plantas medicinales, aromáticas o venenosas de Cuba". Editorial Científico Técnica, La Habana, Cuba (2014): 618-619.

3. PEREZ TG., et al. "Evaluation of the antioxidant activity of gossypitrin by in vitro and in vivo assays". Revista Mexicana de Ciencias Farmacéuticas 32.2 (2001): 19-24.

4. José González., et al. "Antibacterial and Antifungal Activities of Gossypitrin from Talipariti elatum Sw. (Fryxell)'. International Journal of Current Microbiology and Applied Sciences 5.11 (2016): 860-866.

5. José González., et al. "Antioxidant activity of gossypitrin isolated from the petals of Talipariti elatum (Sw.) Fryxell (Malvaceae) in Cuba". International Journal of Engineering Research and Science (IJOER) 3.10 (2017): 17-22.

6. Bécquer-Viart MA., et al. "Antioxidant and neuroprotective effects of gossypitrin, a flavonoid from Talipariti elatum, against chemical hypoxia-induced PC12 cell death". Journal of Pharmacy and Pharmacognosy Research 6.2 (2018): 72-80.

7. Frantz François-Haugrin., et al. "Antioxidant activity of an isomer of gossypitrin (gossypetin-3'-0-glucoside) isolated in the petals of Talipariti elatum Sw., and determination of total phenolic content of the total flower". Journal of Pharmacognosy and Phytochemistry 5.5 (2016): 200-208.

8. Simirgiotis MJ., et al. "Identification of phenolic compounds from the fruits of the mountain papaya Vasconcellea pubescens A. DC. grown in Chile by liquid chromatography-UV detection-mass spectrometry". Food Chemistry 115 (2009): 775784.

9. Catarino MD., et al. "Characterization of phenolic constituents and evaluation of antioxidant properties of leaves and stems of Eriocephalus africanus". Arabian Journal of Chemistry (2015).

10. Domon B and Costello CE. "A Systematic Nomenclature for Carbohydrate Fragmentations in FAB-MS/MS of Glycoconugates". Glycoconjugate Journal 5.4 (1988): 397-409.

11. Ma YL., et al. "Characterization of flavone and flavonol aglycones by collision-induced dissociation tandem mass spectrometry". Rapid Communications in Mass Spectrometry 11.12 (1997): 1357-1364.

12. Pedro FP and Gonçalo C J. "Structural Analysis of Flavonoids and Related Compounds-A Review of Spectroscopic Applications, Phytochemicals-A Global Perspective of Their Role in Nutrition and Health". Edited by Dr. Venketeshwer Rao (2012).

13. Kajdžanoska M., et al. "HPLC-DAD-ESI-MSn Identification of Phenolic Compounds in Cultivated Strawberries from Macedonia". Macedonian Journal of Chemistry and Chemical Engineering 29.2 (2010): 181-194.

14. Yaque JG., et al. "Isolation and Characterization of Flavonols by HPLC-UV-ESI-MS/MS from Talipariti elatum S.w". American Journal of Plant Sciences 7 (2016): 1198-1204.

15. Giguet-Valard AG., et al. "Gossypetin Derivatives are also Putative Inhibitors of SARS-COV 2: Results of a Computational Study". Journal of Biomedical Research and Environmental Sciences 1.6 (2020): 201-212.

\section{Assets from publication with us}

- Prompt Acknowledgement after receiving the article

- Thorough Double blinded peer review

- Rapid Publication

- Issue of Publication Certificate

- High visibility of your Published work

Website: www.actascientific.com/

Submit Article: www.actascientific.com/submission.php

Email us: editor@actascientific.com

Contact us: +919182824667 